\title{
Visiting Tamburlaine's tomb: drama and performance in early seventeenth-century travel writing
}

Article

Accepted Version

Houston, C. (2019) Visiting Tamburlaine's tomb: drama and performance in early seventeenth-century travel writing. Renaissance Studies, 33 (4). pp. 568-589. ISSN 1477-4658 doi: https://doi.org/10.1111/rest.12568 Available at https://centaur.reading.ac.uk/79628/

It is advisable to refer to the publisher's version if you intend to cite from the work. See Guidance on citing.

To link to this article DOI: http://dx.doi.org/10.1111/rest.12568

Publisher: Wiley

All outputs in CentAUR are protected by Intellectual Property Rights law, including copyright law. Copyright and IPR is retained by the creators or other copyright holders. Terms and conditions for use of this material are defined in the End User Agreement.

www.reading.ac.uk/centaur 
Central Archive at the University of Reading

Reading's research outputs online 
Dr Chloë Houston, University of Reading, c.houston@reading.ac.uk

\section{Visiting Tamburlaine's tomb: drama and performance in early seventeenth- century travel writing.}

\section{Introduction: travel and drama on the early modern stage}

The interconnections between the literature of travel and dramatic performance have gradually taken centre stage in scholarship on the relationship between performance and context in early modern English drama. 'The concepts of travel and drama,' as Jean-Pierre Maquerlot and Michèle Willems argued twenty years ago in the introduction to their influential collection of essays Travel and Drama in Shakespeare's Time, 'are essentially productive through their confrontation'.1 Much early modern drama can profitably be understood as taking place within a global context, and many plays engaged both directly and indirectly with travel in myriad ways: with travel maps and other documents, with records of journeys and foreign encounters, with the people who travelled and the people they met and about whom they wrote. Now, as Jyotsna Singh has commented, it 'would be a critical commonplace to suggest that the very name of Renaissance London's Globe Theatre evoked the drama's engagement with England's role in the expanding world of exploration and trade'. ${ }^{2}$ A number of scholars, including Richmond Barbour, Jonathan Burton, Matthew Dimmock, Claire Jowitt, Daniel J. Vitkus, and others, have enriched our understanding of the various ways in which

\footnotetext{
${ }^{1}$ Jean-Pierre Maquerlot and Michèle Willems, eds, Travel and Drama in Shakespeare's Time (Cambridge: Cambridge University Press, 1996), 1.

2 Jyotsna G. Singh, "Introduction: The Global Renaissance", in A Companion To The Global Renaissance: English Literature and Culture in the Era of Expansion, ed. by Jyotsna G. Singh (Oxford: Wiley-Blackwell, 2009), 21.
} 
plays of the early modern period responded to the increase both in travel and in various forms of travel literature in the later sixteenth and seventeenth centuries. $^{3}$

Christopher Marlowe's Tamburlaine the Great plays, first performed in 1587 and 1588, have provided rich pickings for scholars interested in the imaginative relationship between drama and travel. The global context of the Tamburlaine plays has focused critical attention for a number of years: Stephen Greenblatt suggested in 1992, for example, that Tamburlaine typifies 'the acquisitive energy of merchants and adventurers, promoters alike of trading and theatrical companies,' and John Gillies in 1994 discussed how maps and other documents of travel influenced the 'imaginative geography' of Marlowe's two plays. ${ }^{4}$ Since then, scholars have explored the ways in which Marlowe's creation of Tamburlaine was influenced by the expansion of English people's capacity for trade and travel, addressing the questions of how Marlowe's plays can be placed within a global context, how they made use of maps and other documents of travel, and how they both responded to and fed playgoers' awareness of the world beyond English and European borders. ${ }^{5}$

\footnotetext{
${ }^{3}$ See for example: Richmond Barbour, Before Orientalism: London's Theatre of the East, 1576-1626 (Cambridge: Cambridge University Press, 2003); Jonathan Burton, Traffic and Turning: Islam and English Drama, 1579-1624 (Newark: University of Delaware Press, 2005); Matthew Dimmock, New Turkes: Dramatizing Islam and the Ottomans in Early Modern England (Aldershot: Ashgate, 2005), Claire Jowitt, Voyage Drama and Gender Politics 1589-1642: Real and Imagined Worlds (Manchester: Manchester University Press, 2003); Daniel J. Vitkus, Turning Turk: English Theater and the Multicultural Mediterranean, 1570-1630 (Basingstoke: Palgrave Macmillan, 2003).

${ }^{4}$ Stephen Greenblatt, "Marlowe and the Will to Absolute Play", in New Historicism and Renaissance Drama, ed. by Richard Wilson and Richard Dutton (London: Longman, 1992), 58; John Gillies, Shakespeare and the Geography of Difference (Cambridge: Cambridge University Press, 1994), 53.

${ }^{5}$ See for example Emily C. Bartels, Spectacles of Strangeness: Imperialism, Alienation, and Marlowe (Philadelphia: University of Pennsylvania Press,1993), Chapter 3; Thomas Cartelli, "Marlowe and the New World", in Christopher Marlowe and English Renaissance
} 
This article seeks to add to the growing field of scholarship that considers the relationship between travel and drama from the opposite direction, asking not how travel and its literature influenced drama, but how drama influenced travel and its literature, and the everyday experience of early seventeenth-century travel writers in particular. In his essay for Travel and Drama in Shakespeare's Time, Peter Holland remarked that 'we tend rather glibly to talk of a play as a journey'. ${ }^{6}$ One might also observe that early modern travel writers, in making references to the world of the theatre, and in constructing themselves and the people they encountered as both actors and audiences, tended to talk of a journey as though it were a play. The theatricality or performativity of early modern travel writing has received increasing critical attention in recent years. In a collection of essays edited by Sabine Schülting, Sabine Lucia Müller, and Ralf Hertel in 2012, Gerald MacLean wrote that 'performativity proves a useful way of examining AngloOttoman diplomatic encounters of the early modern period', and one might profitably expand that judgment beyond English encounters with the Ottoman Empire. ${ }^{7}$ Schülting, Müller and Hertel argued that the scope opened up by performativity studies [...] implies a radically new perspective on all kinds of cultural practices, including textual production and reception'.8 Paying attention

Culture, ed. by Darryll Grantley and Peter Roberts (Aldershot: Ashgate, 1999), 110-18; Crystal Bartolovich, "Putting Tamburlaine on a (Cognitive) Map", in The Space of the Stage, ed. by Jeffrey Masten and Wendy Wall (Evanston: Northwestern University Press, 1999); Bernhard Klein, "Tamburlaine, sacred space, and the heritage of medieval cartography", in Reading the Medieval in Early Modern England, ed. by Gordon McMullan and David Matthews (Cambridge: Cambridge University Press, 2007).

${ }^{6}$ Holland, “'Travelling Hopefully", 160.

${ }^{7}$ Gerald MacLean, "Performing at the Ottoman Porte in 1599: The Case of Henry Lello", in Early Modern Encounters with the Islamic East: Performing Cultures, ed. by Sabine Schülting, Sabine Lucia Müller, and Ralf Hertel (Farnham: Ashgate, 2012), 32.

8 Sabine Schülting, Sabine Lucia Müller, and Ralf Hertel, "Introduction: Cultures at Play", Early Modern Encounters with the Islamic East, 2. 
to the performativity of early modern travel writing not only elucidates the various performances undertaken and observed by travellers themselves, but also the problems and tensions that such performances revealed, and sometimes sought to resolve.

The widespread use of dramatic experience in the travel literature of the early to mid-seventeenth century shows how travellers turned to the language and experience of drama - both as spectator and as player - to describe their experiences in and impressions of foreign places. This article considers how the experience of participating in theatrical spectacle was present for English travel writers in their encounters with and descriptions of foreign lands, peoples and experiences, and the ways in which the metaphors of drama were convenient for them. It will then turn to Marlowe, looking at how travellers used the figure of Tamburlaine in their experiences and descriptions of foreign lands. In explaining his desire to travel into Asia, the English traveller Thomas Coryate (c. 1577-1617), who journeyed through Europe into Asia, apparently on foot, in the early years of the seventeenth century, spoke of his yearning to 'visit the blessed Sepulcher of [...] Tamberlaine [...] whose fame [...] is published ouer the whole world'. ${ }^{9}$ The Tamburlaine of his imagination was not only the historical figure known to the early modern period through historical writings but the dramatic creation of Marlowe's plays, whose rhetoric, Jonathan Gil Harris has recently argued, influenced Coryate's own style of speech. ${ }^{10}$ When travellers like Coryate and his

${ }_{9}^{9} \mathrm{Mr}$ Thomas Coriat to his friends in England sendeth greeting (London, 1618), $1^{\text {st }}$ verso after B2v.

10 Jonathan Gil Harris, The First Firangis (New Delhi: Aleph, 2015), x. 
contemporaries referred to 'Tamerlane', to what extent were they thinking of Marlowe's creation, rather than the historical figure?

It is only relatively recently that the ways in which plays engaged with the practicalities, rather than only the idea, of travel, or 'imaginative geography', have come to be investigated in detail, with scholars such as Vitkus and Holland considering in different ways how the actual experience of travel was portrayed on the early modern stage. ${ }^{11}$ In a recent article on the representation of the 'travail' of travel in Dekker's Old Fortunatus and Shakespeare's Pericles, Vitkus showed how the drama of the Elizabethan and Jacobean periods represented the journey on stage in sometimes contradictory ways: to simplify, travel can be represented both 'as painful ordeal and as fantastic fun.' In doing so, he argued, the plays register 'a tension between the notion of travel as labor or "travail" and, in contrast, an emerging, modern conception of travel's purpose as a satisfying venture, as commercial exchange, commodity acquisition, or knowledge acquisition.' Often, he went on to suggest, this tension is 'resolved when the sacrifices and deprivations of travel are ultimately redeemed by the gains of those who endure the test of travel.' ${ }^{12}$ I want to suggest that the use of dramatic metaphor and language in the travel writing of this period functioned in a similar manner, to resolve tensions encountered by travellers as they sought to navigate, understand and represent the foreign places and peoples that they encountered.

\footnotetext{
11 Peter Holland, “'Travelling Hopefully': The Dramatic Form of Journeys in English Renaissance Drama", in Travel and Drama in Shakespeare's Time; Daniel J, Vitkus, "Labor and Travel on the Early Modern Stage: Representing the Travail of Travel in Dekker's Old Fortunatus and Shakespeare's Pericles", in Working Subjects in Early Modern English Drama, ed. by Michelle M. Dowd and Natasha Korda (Farnham: Ashgate, 2011).

12 Daniel Vitkus, "Labor and Travel on the Early Modern Stage: Representing the Travail of Travel in Dekker's Old Fortunatus and Shakespeare's Pericles", in Working Subjects in Early Modern English Drama, ed. by Michelle M. Dowd and Natasha Korda (Farnham: Ashgate, 2011), 233, 228.
} 
In many travel books, both acting and spectating become strategies for successfully maintaining the traveller's image, both during his own experience and, later, in print.

\section{Theatrical metaphor in English travel writings: truth and duplicity}

It is not especially common for English travel writings of the late sixteenth or early seventeenth centuries to refer to a contemporary play directly. Texts that mention a specific play or character are unusual within the broader canon of travel literature, and usually uncommon even within the writings of the traveller in question. (When Thomas Roe mentions Tamburlaine in his description of a gift he received from the Emperor Jahangir's son, Prince Khurram, it is the only direct reference to a contemporary play in this record of his travels. ${ }^{13}$ ) But what we might describe as the language of performance - descriptions of a particular environment as appearing to be like a theatre, or a person behaving like a player, or a certain object looking like a theatrical prop or costume - was relatively common. In recent years, a number of studies have discussed the ways in which travel writers made use of dramatic experience in their narratives, and paying attention to the use of dramatic metaphor has been proved a useful means of learning about the cultural work done by the travel literature of this period. ${ }^{14}$

\footnotetext{
${ }^{13}$ Colin Paul Mitchell, Sir Thomas Roe and the Mughal Empire (Karachi: The Area Study Centre for Europe, 2000), 76-7.

14 See for example Kate Teltscher, India Inscribed: European and British Writing on India 1600-1800 (Delhi: Oxford University Press, 1995); Jyotsna Singh, Colonial narratives/ cultural dialogues: "discoveries" of India in the language of colonialism (London: Routledge, 1996); Barbour, Before Orientalism; Sabine Schülting, Sabine Lucia Muller and Ralf Hertel, eds, Early Modern Encounters with the Islamic East: Performing Cultures (Farnham: Ashgate 2012).
} 
The writers of travel narratives available to the English readership during this period generally use the language of theatre for two main reasons: firstly, to describe the physical appearance of a person or place, and secondly, to describe behaviour, whether of the travel narrator himself, or of a person encountered while travelling. In doing so, the traveller is usually employing language of the theatre in order to depict a person or place accurately or to make it comprehensible to the reader. So when Fernão Lopes de Castaneda writes of the court at Coching (Kochi) in India that 'The king himselfe was sitting within certeine grates, made much lyke a Theatre, with the which the whole house was compassed aboute', he is using the image of the theatre in order to help the reader picture a physical environment which is unfamiliar. ${ }^{15}$ And when Thomas Roe describes one of Jahangir's servants as 'cloathed as rich as any Player, and more gaudy', he is calling to mind a visual image that quickly informs his reader of the quality of the servant's clothing and the concomitant richness of Jahangir's court. ${ }^{16}$

But as Roe's depiction of the servant also demonstrates, such images, though seemingly straightforward, are often more complex in their effects. In this case, the description of the servant as being dressed like a player contributes to the impression of Jahangir's progress in his new coach as an explicitly theatrical event. It also suggests a certain disdain for the servant: his clothing, though 'rich' in appearance, is, like an actor's costume, meaningless in itself. Furthermore, given that the servant referred to is English, the comparison of him to an actor heightens the sense of the servant as engaged in more than one performance: he is an

\footnotetext{
15 Fernão Lopes de Castaneda, The first booke of the historie of the discouerie and conquest of the East Indias, enterprised by the Portingales, in their daungerous nauigations (London, 1582), 91.

16 Thomas Roe, in Hakluytus Posthumus or Purchas His Pilgrimes. In Five Bookes, ed. by Samuel Purchas (London, 1625), I, 559.
} 
Englishman acting the role of servant to Jahangir, a role that is perceived as being not properly his own. As is often the case, the comparison to a player contains a judgment about the false or duplicitous nature of the activity in which the servant is engaged.

Thus theatrical metaphor in the travel writing of this period is employed to indicate the falseness of the witnessed person, object or spectacle, to highlight its insincerity or lack of true meaning. But this in itself creates a tension in travel narratives, because, as we will see, travellers often used theatrical metaphors to describe themselves, and their own behaviour and experience. Fynes Moryson, for example, explained the necessity for the Protestant traveller attending a Catholic mass abroad to mimic the gestures of the congregation, despite the discomfort which this might cause. Moryson defends the impetus to attend Mass as a form of curiosity, much like, in fact, the impetus to attend the theatre: 'if any will needs be present at their Masses, either to please his companions, or for his owne pleasure, as going to see a stage-play, or for curiositie, wherewith many are led'. This is a play, however, in which the traveller must play a part, taking care 'to signe himselfe with the crosse, or negligently to make offer, as if he dipped his hand (or his gloue vpon it, as their manner is) into the holy water-Box'. Travellers who neglect to perform these rituals - or rather, who neglect to pretend to perform them, as Moryson is clear that one may 'make offer, as if completing the gesture, rather than actually doing it - may find themselves objects of suspicion to their hosts. Of course, Moryson is aware that Protestant travellers who attended Catholic mass while living abroad were equally likely to come under suspicion when they returned home of having actively participated in Catholic ritual. The exhortation to pretense is thus a rhetorical device which distances the traveller/ 
writer from the double risk in which he finds himself, open to suspicion both from his Catholic hosts when abroad, and from his Protestant readership when at home. The use of theatrical metaphor is in this sense an attempt to resolve potential tensions which travellers experienced as actors on both the foreign and the domestic stage. European travellers were themselves caught up in the theatrical events they witnessed and described, and they often found themselves obliged to act, or dissemble, or be false. So the metaphors of acting and the theatre functioned as a way of allowing them to explain the necessity and effect of this kind of pretense in a manner that was easily comprehensible, and that made their behaviour excusable. In Moryson's account, he is quick to emphasise that the penalties faced by travellers who do not perform adequately are serious: 'being called into question,' he may 'either be driuen to denie his Religion vnder his hand writing, or be burned with fire'. Let those who wish to martyr themselves do so, Moryson suggests, but 'inordinate desire of Martyrdome is not approueable'; better to act, to dissemble, when necessary, than to risk a greater penalty. ${ }^{17}$

\section{Thomas Roe and Thomas Coryate: travellers as spectator-actors}

Travellers like Roe and Coryate often found - or put - themselves in the role of spectator in the theatrical metaphor. This is to be expected, given that their stated reasons for travel usually included the desire to see, as Coryate explains in his report of his speech to the Moghul Emperor Jahangir, in which he states his motivations for coming to India: 'to see your glorious Court [...] to see your

17 Fynes Moryson, "Of Precepts for Travellers", in An Itinerary, Containing His Ten Yeeres Travell (1617; Glasgow: James MacLehose and Sons, 1907), III, 415 [III.i.32]. 
Maiesties Elephants [...] to see your famous Riuer Ganges', and so on. ${ }^{18}$ For Coryate, seeing was a primary motive for travelling, and thus the world was a theatre through which a man might move and learn:

such is the sweetnesse of travelling and seeing the world, such the pleasure, such the delight, that I thinke that man voyde of all sense, and of a stony hardnes, which cannot be said to be moved with so great pleasure, that he had rather remaine in his owne house, as it were in a prison or gaole, then to converse in the most beautifull Theatre of nature, and the full court of all delights. ${ }^{19}$

In recording his experiences as a member of the audience in the 'Theatre of nature' or 'that most beautifull Theatre of the Universe', as Singh has noted, Coryate's 'mode of dramatic description is permeated by references to seeing - and to his role as spectator.' For Coryate, dramatic metaphor provided a means of describing his way of being and seeing when abroad. ${ }^{20}$

To describe themselves as spectators in a theatre allowed Coryate and Roe to convey their passivity in environments over which they had little control, and in which they wished to observe and record the spectacles of the foreign court. The metaphor of traveller as audience member also permitted the writer to ally himself rhetorically with the reader of his own text, who shared the position of observer, one degree removed. This rhetorical strategy is especially evident in texts where the writer wished the reader to share his own perspective. Roe, for example, in his letters to the East India Company, emphasizes the potential

\footnotetext{
18 Thomas Coryate, $M r$ Thomas Coriat to his friends in England sendeth greeting from Agra the capitall city of the dominion of the great Mogoll in the Easterne India (London, 1618), in Purchas his Pilgrimes, iv, 482-488.

19 Thomas Coryate, "An Oration of praise of Travell in generall", Coryats crudities hastily gobled up in five moneths trauells... (London, 1611), C4r.

${ }^{20}$ Jyotsna Singh, Colonial narratives/ cultural dialogues: "discoveries" of India in the language of colonialism (London: Routledge, 1996), 43-4.
} 
'compatibility between England and the Mughal Empire'; presenting himself as a spectator thus allies his own interests and position with those of the Company. ${ }^{21}$

In her study of European and British writing about India in the seventeenth and eighteenth centuries, Kate Teltscher argued that the use of theatrical metaphor in Roe's travel writings is a way of drawing 'explicit comparison with the familiar' in creating a frame of reference for the reader and helping to describe visual elements of the foreign court. ${ }^{22}$ That is, the metaphor of foreign court as theatre provides the reader with an easy frame of reference, the playhouse: if travellers are audiences, then the theatres they visit are foreign courts, and the actors are the rulers and courtiers who populate them. Teltscher also argued that the theatrical metaphor connotes unreality:

The image of the theatre, which Roe claims to be an exact representation of the court, is itself most commonly used as a symbol of unreality or feigning. Indeed Roe's whole conception of the Mughal court is shot through with a sense of unreality. ${ }^{23}$

In recording their experiences as spectators, English travel writers conveyed both their closeness to the events taking place in front of them, and their separation from them. Roe is scathing about the behaviour of the Persian ambassador, whom be judges to seem 'rather a Jester or Behaviour of Jugler, then a person of any gravity, running up and downe and acting all his words like a Mimicke Player' in presenting his gifts to the King. This event taking place before Roe himself has met the King in person, Roe remains separated from the action of the court, and disdainful of the Persian ambassador's performance within it:

When all was delivered for that day, hee prostrated himselfe on the

\footnotetext{
${ }^{21}$ Rahul Sapra, The Limits of Orientalism: Seventeenth-Century Representations of India (Newark: University of Delaware Press, 2011), 70.

22 Kate Teltscher, India Inscribed: European and British Writing on India 1600-1800 (Delhi: Oxford University Press, 1995), 20.

23 Teltscher, India Inscribed, 20.
} 
ground, and knocked with his head, as if hee would enter in. [...] This is but the first act of his presenting, the Play will not be finished in ten dayes.

As a spectator, Roe judges the Persian ambassador's performance and finds it wanting; finds it wanting because it is a performance. But as he draws closer to the King and becomes involved in the rituals surrounding royal audiences and giftgiving, Roe finds himself acting as both spectator and player on this foreign stage. He describes the ritual of the King's arrival for his audience:

In the middest of this Court was a throne of mother of Pearle, borne on two pillars raised on earth, covered over with an high Tent, the pole headed with a knob of gold, under it Canopies of Cloath of gold, under- foot Carpets. When the King came neare the doore, some Noble-men came in, and the Persian Embassador: we stood one of the one side, the other of the other, making a little lane: the King entring cast his eye on me, and I made a reverence; he laid his hand on his brest and bowed, and turning to the other side, nodded to the Persian. I followed at his heeles till he ascended, and every man cryed good, joy, and fortune, and so tooke our places. He called for water, washed his hands and departed.

Now Roe is closer to the King - 'at his heeles' - he is also an actor, making a reverence at the appropriate moment, standing in formation with other courtiers and visitors, speaking on cue. Presence at the King's audience often involves this overlapping of Roe's role as spectator with his growing role as an actor. In this description of another experience of the King's audiences, is Roe on stage as a member of the audience, or as a player himself?

I found him in a Court, set above like a King in a Play, and all his Nobles and my selfe below on a stage covered with carpets; a just Theater: with no great state, but the Canopies over his head, and two standing on the heads of two wooden Elephants, to beat away flies.

The distaste for or mistrust of performance (because it is essentially false) is thus complicated by the fact that the distance necessary for the traveller to remain in role of spectator is eroded by the necessity of taking part in the events on stage. Theatrical metaphor has a double function, in suggesting a foreign court's likeness to a place that is at once real and unreal; it also has a double function in allowing 
the traveller-writer to present himself as both spectator and actor. In such descriptions, the boundaries of the theatrical space and theatrical roles are unfixed. Roe describes the experience of watching the Emperor's durbar at his camp in Ajmer, initially in the role of spectator. After a while, he perceives that he is himself being watched by the Emperor's wives, 'whose curiositie made them breake little holes in a grate of Reed that hung before it, to gaze on mee.' Roe perceives that he has become an object of interest and entertainment himself: 'When I looked up they retyred, and were so merry that I supposed they laughed at mee.' 24

As often as they were spectators in the theatre of the world, then, travellers found themselves participating in the theatrical activity they witnessed around them, either deliberately or by inadvertently entering a performance space. The imaginative potential of the theatrical metaphor described and emphasized the traveller's double role as spectator and actor; this doubleness often produced an awkwardness or tension, which the use of theatrical metaphor also attempted to diffuse; by likening the foreign court to a stage, it put the traveller on the boundaries of the playing space, like an audience member seated on the stage itself, on the edge of theatrical action.

\section{Travellers as actors: the necessity of performance}

As Gerald MacLean wrote in Looking East: English Writing and the Ottoman Empire Before 1800, 'all ambassadors are actors'. 25 That ambassadors like Roe,

\footnotetext{
24 Thomas Roe, Letter from the Mughal Court, in Samuel Purchas, Hakluytus Posthumus or Purchas His Pilgrimes. In Five Bookes....(London, 1625), I, 581.

25 Gerald MacLean, Looking East: English Writing and the Ottoman Empire Before 1800 (Basingstoke: Palgrave Macmillan, 2007), 97.
} 
and those who travelled for other purposes, were obliged to perform a variety of roles during their travels has been well documented; for one thing, travellers in potentially hostile situations often had to 'pass themselves off' as having a different nationality or religion from their own. ${ }^{26}$ Jyotsna Singh describes the multiple roles that Coryate performed during his time in Mughal India, arguing that Coryate's 'participation in Indian culture, especially in taking on a native persona, enabled him to display his love of histrionics and shape his account as a dramatic fable'. ${ }^{27}$ Coryate's role as 'daring actor' is necessitated by his lack of material support; he learns vernacular languages on his travels in order to be able to perform to a wider range of audiences. So, for example, Coryate's capacity to perform to Jahangir in a language the emperor could understand, making a flattering oration to him in fluent Persian, earns him a reward of 100 rupees, money that he sorely needed. For Coryate, performance was a means of survival, as well as a mode of description that enhanced his account of his travels. When in attendance at court, whether at Jahangir's court or European courts closer to home, the traveller was obliged to follow a code of behaviour and gesture that emphasized the performative nature of courtly life and their role within it. $^{28} \mathrm{~A}$

\footnotetext{
${ }^{26}$ Rahul Sapra, The Limits of Orientalism: Seventeenth-Century Representations of India (Newark: University of Delaware Press, 2011), 72.

27 Jyotsna Singh, Colonial narratives/ cultural dialogues: "discoveries" of India in the language of colonialism (London: Routledge, 1996), 45.

${ }^{28}$ The necessity for travellers to perform in this way was, of course, limited neither to attendance at non-European courts nor to English travellers. Castiglione's The Book of the Courtier (1561) and other courtier handbooks encouraged similarly theatrical modes of self-presentation. On this see Timothy Hampton, Fictions of Embassy: Literature and Diplomacy in Early Modern Europe (Ithaca: Cornell University Press, 2012), Introduction, and Ellen R. Welch, $A$ Theater of Diplomacy: International Relations and the Performing Arts in Early Modern France (Philadelphia: University of Pennsylvania Press, 2017), p. 35. I am grateful to the anonymous reviewer for pointing out the applicability of this argument to European as well as non-European ambassadors.
} 
number of travellers record the necessity of observing the correct appearance and gesture in the presence of a ruler; at the Mughal court, for example, the correct position in which to stand before Jahangir was with arms crossed, the fingertips of each hand touching the opposite elbow, standing to attention and ready to receive and obey the emperor's commands. ${ }^{29}$

Travel narratives often promoted the capacities for acting and improvisation that travellers needed to display as useful strategies in negotiating foreign environments, but in doing so also emphasized the necessity of such strategies and the potential risks inherent in neglecting them. So Henry Blount's $A$ Voyage into the Levant (1636) presents Blount as 'a gifted actor on the Eastern stage', as 'Blount propagates disguise, flexibility and improvisation as successful strategies that should be adopted by those following him'. 30 Blount's performances, as Sabine Schülting shows, are tactical, demonstrating to his readership a successful method of dealing with the Turks: 'due to his strategic performance, Blunt is able not only to save his life and avoid enslavement, but also to "win over" his Ottoman counterparts'31. Nonetheless, they are performances which he is obliged to undertake: Blount must act and improvise in order to succeed, even to survive. For example, at one point in his narrative Blount is at risk when he encounters four members of the Ottoman cavalry, who address him in a manner that seems to Blount to be hostile, although he is unable to understand their language:

${ }^{29}$ The Mughal World: Life in India's Last Golden Age, Abraham Eraly (New Delhi: Penguin, 2007), 47.

30 Sabine Schülting, "Strategic Improvisation: Henry Blount in the Ottoma Empire", in Early Modern Encounters with the Islamic East: Performing Cultures, ed. by Sabine Schülting, Sabine Lucia Müller, and Ralf Hertel (Farnham: Ashgate, 2012), 67-82, 68.

31 Schülting, 82. 
Seeing by my head, I was a Christian, they called to me; I not understanding what they would, stood still, till they menacing their weapons, rose, and came to mee, with looks very ugly. 32

As they approach him in this threatening manner, Blount is obliged to abandon his first strategy of doing nothing, and to speak to them in English, as he cannot communicate in Arabic or Ottoman Turkish. The words that he uses are potentially unfriendly, but the manner in which he speaks them is supplicatory, and has the desired effect:

I smiling met them, and taking him who seemed of most port, by the hand, layed it to my forehead, which with them is the greatest signe of love, and honour, then often calling him Sultanum, spoke English, which though none of the kindest, yet I gave it such a sound, as to them who understood no further, might seeme affectionate, humble, and hearty; which so appeased them, as they made me sit, and eate together, and parted loving. (p. 98). Here, the tactical performance is successful, but it is necessitated by a potentially dangerous situation, over which the traveler-narrator has very little control.

Thomas Roe provides a useful case study of courtly performance abroad and its complexities, and the necessity of acting. A primary function of his commission to India was to present himself in a manner that would command respect for England, its mercantile capacity and its status in the world, but he was hampered by the inadequate resources made available to him by his commissioners. 33 Roe was obliged to perform a number of identities simultaneously: as an ambassador, he represented the person of the monarch, as well as the commercial interests of the East India Company who had commissioned him. He also had to perform in a manner appropriate to the Mughal court; MacLean's Looking East has examined how ambassadors in particular 'performed East', and MacLean has explored further the ways in which such

\footnotetext{
32 Henry Blount, $A$ Voyage into the Levant (London, 1636), 98.

33 Barbour, Before Orientalism, 146.
} 
travellers needed to understand and 'perform' foreign protocols. ${ }^{34}$ The multiple layers of performance are again brought to the fore, as the traveller both inhabits his own nationality or identity and performs that of his commissioners as well as that of his hosts. As MacLean has pointed out, some managed this with more success than others; if the efforts of English ambassadors to Muslim emperors sometimes failed, he argues, 'this may well have had something to do with the ways in which they performed East'. ${ }^{35}$ Ambassadors like Roe were also obliged to perform, but were not in control of the effects of their performances. Roe himself seems to have been an active performer, but not a very self-aware one, often appearing to be ignorant of the fact that his own 'imperious manner' failed to impress his imperial audiences. ${ }^{36}$

There are a number of ways in which travellers like Roe were not in control of the multiple stages on which they performed. For one thing, foreign courts, with their new and strange habits, languages and rituals, were unfamiliar environments in which to play a part, and with little time available for rehearsal. Travellers encountering these spaces entered into performances which were frequently directed, even scripted, by others. Often, too, the narratives which presented a traveller's experience to the reading public 're-staged' those experiences for the audience at home. So, for example, the writings about William Harborne in Richard Hakluyt's Principal Navigations attempt to present him as 'a successful performer for his country's interests'. ${ }^{37}$ In doing so they gloss over details which might interfere with this interpretation, notably 'the early modern

\footnotetext{
34 MacLean, "Performing at the Ottoman Porte in 1599", X.

35 MacLean, Looking East, 112.

36 MacLean, Looking East, 115.

${ }^{37}$ Sabine Lucia Müller, "William Harborne’s Embassies: Scripting, Performing and Editing Anglo-Ottoman Diplomacy", in Early Modern Encounters with the Islamic East, 11-26, 12.
} 
English arms trade and failed attempts at Anglo-Ottoman political alliances.'38 Hakluyt's collection of materials on Harborne's embassy (Harborne was the first English ambassador to the Ottoman Empire), may have 'an "ad hoc" quality', including eyewitness accounts alongside official documents like Harborne's commission from the Queen, but nonetheless constitute a careful staging or representation of his mission in the Ottoman Empire and its perceived success. Ambassadors like Harborne, Müller notes, performed for a 'double audience': both the 'representatives of Ottoman power during the time of reported action' and 'the intended readership of the subsequent letters and reports'. ${ }^{39}$ Such performances were stage-managed first by the courtly rituals and ceremonies in which they participated, and (in many cases) a second time by the editors of the texts in which their travel accounts appeared.

Many travellers, unsurprisingly, registered awkwardness at their (sometimes enforced) role as players. Thomas Roe recorded his discomfort on being given a piece of gold cloth by Sultan Khurram, the son of Emperor Jahangir. In his own eyes, the gift transformed Roe into a player, wearing an elaborate costume:

By and by came a Cloath of gold Cloake of his owne, once or twice worne, which hee caused to be put on my backe, and I made reference very unwillingly. When his Ancestor Tamerlane was represented at the Theatre, the garment would well have become: but it is heere reputed the highest favour to give a garment worne by a Prince. ${ }^{40}$

As Richmond Barbour has argued, Roe felt that the gift of the robe made him a 'mimic', diminishing his status. ${ }^{41}$ Roe registers discomfort at the idea of being

\footnotetext{
38 Müller, "William Harborne's Embassies", 13.

${ }^{39}$ Müller, "William Harborne's Embassies", 11, 28.

40 Purchas, iv, 381.

${ }^{41}$ Barbour, Before Orientalism, 172.
} 
made into a player; Kate Teltscher emphasizes his refusal to participate in theatrical spectacle, typical of his desire to remain

an observer of the spectacular display of excess, a mediator between the Eastern fiction and the Western audience. While the whole court is engaged in the 'flattery and obsequiousnesse' of false theatrical spectacle, Roe represents sincerity and sober reality. 42

That Roe represents these qualities in the text is of course another performance, or restaging of Roe's experiences for his reading audience. It is a further example of tactical performance, in which acting was often a necessary strategy. The use of theatrical metaphor in travel writing was also a strategy, both for describing travellers' experiences and for containing the tensions that arose out of the double nature of the traveller's role. In the next section, we will examine the representation in travel writing of the highly celebrated performance that the Sultan's gift brought to mind for Roe: Christopher Marlowe's Tamburlaine.

Tamburlaine abroad: the historical Timur and Marlowe's Tamburlaine in the literature of travel

By the later sixteenth century, there was a wide range of material available on the historical Tamburlaine or Tamerlane (c. 1336-1405), more properly Timur or Temur. ${ }^{43}$ Timur himself is supposed to have written an autobiography, and to have commissioned contemporary histories of his rule, which were expanded by later Arabic and Turkish historians. ${ }^{44}$ Eastern European authors also wrote

\footnotetext{
42 Kate Teltscher, India Inscribed: European and British Writing on India 1600-1800 (Delhi: Oxford University Press, 1995), 22.

43 Temur is the Turkic version of Tamerlane, which derives from the Persian Timur-I lang or Temur the lame. On Tamburlaine's name, see Beatrice Forbes Manz, The Rise and Rule of Tamerlane (Cambridge: Cambridge University Press, 1989), p. 1. For the sake of clarity, in this article I will refer to the historical figure as Timur, in order to distinguish him from the fictional Tamburlaine of Marlowe's plays.

${ }^{44}$ Ron Sela, The Legendary Biographies of Tamerlane: Islam and the Heroic Apocrypha in Central Asia (Cambridge: Cambridge University Press, 2011), 10-13.
} 
histories of Timur, which were circulating in Western Europe by the late 1500s. ${ }^{45}$ Western European historians had by then developed their own body of work on Timur, some of which claimed to be based upon Arabic sources. ${ }^{46}$ By the later sixteenth century Western European readers were familiar with the name and story of Timur, and particularly with his defeat of the Ottoman Emperor Bayezit or Bajazet I in 1402, which prevented the fall of Constantinople to the Ottoman Empire, and was thus perceived as a triumph for Christendom over a strengthening Islam. ${ }^{47}$

Marlowe's main source for his Tamburlaine appears to have been George Whetstone's The English Mirrour (1586), a translation of Pedro Mexia's Silva de Varia Lecion (1542). ${ }^{48}$ The Mirrour includes a brief history of the Ottoman Empire as well as a relation of Timur's rise to all-conquering emperor and the subsequent fall of his empire due to discord between his sons. Whetstone's account of Timur registers amazement at his military prowess, praising him for his military discipline and valiance, and shock at his ferocity and cruelty, qualities which are demonstrated in Timur's brutality to his enemies in war. Relating an incident which Marlowe was later to dramatize, Whetstone recounts how the people of Damascus send from their besieged city an embassy of women and children

\footnotetext{
45 Linda McJannet, “'History written by the enemy': Eastern Sources about the Ottomans on the Continent and in England", English Literary Renaissance 36.3 (November 2006), 396-429 (427).

${ }^{46} \mathrm{Du} \mathrm{Bec}$ states that he has based his account of Tamburlaine's life on an Arabic biography; Matthew R. Martin, ed., Tamburlaine the Great Part One and Part Two (London: Broadview, 2014), 15.

${ }^{47}$ Margaret Meserve, Empires of Islam in Renaissance Historical Thought (Cambridge, MA: Harvard University Press, 2008), 215; Matthew R. Martin, ed., Tamburlaine the Great, 16. See also S. S. Artemel, "The idea of Turkey in the Elizabethan period and in the early seventeenth century with special reference to the drama", Durham University, unpublished $\mathrm{PhD}$ thesis, 1965.

48 On Whetstone as Marlowe's source, see T. C. Izard, "The Principal Source for Marlowe's Tamburlaine", Modern Language Notes 58 (1943), 411-17.
} 
clothed in white, which Timur 'caused his squadrons of horsemen to tread [...] under their feete, and not to leave a mothers child a live' ${ }^{49}$ At the same time, in The English Mirrour Timur is 'celebrated both for smashing one of the two biggest threats to proper Christian order [the Ottoman Empire] and for serving as a kind of charm against the other [the Spanish]. ${ }^{50}$ This seems to have been the attitude of a number of other contemporary narrators of the Timur/ Tamburlaine story. ${ }^{51}$ It is also typical of the ways in which the historical Timur was portrayed in travel writing of the period: early modern travel texts lauded Timur for his extraordinary capacity to build his empire and further his own interests, but perceived him as a tyrant who brought terror and ruination. In Heylyn's Cosmographie (1652) Timur is 'furious' and 'mighty', just as in Jean Du Bec-Crespin's earlier biography he is described as being unusually ferocious and physically strong. ${ }^{52}$ As well as recording Timur's capacity for brutality, Du Bec-Crespin's narrative recounts a number of instances of the emperor's good judgement and clemency: after his defeat of Bajazet, Du Bec-Crespin relates how ‘Tamerlan’ refuses Greek Emperor’s offer of his own empire in return for Timur having liberated him from 'the yoke and bondage of the most cruel tiger that might be'. ${ }^{53}$ Aspects of Timur's character and behaviour thus seemed admirable to a Western European readership, despite his reputation for ferocity and ruthlessness. To a Christian European audience,

\footnotetext{
${ }^{49}$ George Whetstone's The English Mirrour, cited in J. S. Cunningham, ed., Tamburlaine the Great (Manchester: Manchester University Press, 1981), 323.

50 See John Gillies, "Marlowe, the Timur myth, and the Motives of Geography", in Playing the Globe: Genre and Geography in English Renaissance Drama, ed. by John Gillies and Virginia Mason Vaughan (London: Associated University Presses, 1998), 227, fn 8. ${ }^{51}$ See John Gillies, "Marlowe, the Timur myth, and the Motives of Geography", 205.

52 Peter Heylyn, Cosmographie (1652), 69, 667; Jean Dubec-Crespin, The History of the Great Emperor Tamerlan (1597), quoted in Martin, Appendix B, 287.

53 Dubec-Crespin, The History of the Great Emperor Tamerlan, quoted in Martin, Appendix B, 296.
} 
Timur's triumphant victories over the Persians and Ottomans had the potential to be 'immensely heartening', and texts that presented Ottoman history for an English audience, such as Richard Knolles' The Generall Historie of the Turkes (London, 1603), sought to present them as such. ${ }^{54}$

Visual representations of Timur provide further information on how he was perceived in early modern England and Europe. Printed books in particular, including travel writings, disseminated images of Timur that give useful evidence for the prevailing beliefs on his ethnicity and character that circulated in sixteenth- and seventeenth-century Europe. ${ }^{55} \mathrm{~A}$ number of engravings from the early seventeenth represent Timur's great military and political power. ${ }^{56}$ Other visual representations could be of direct use to travellers who might employ them to offer to Eastern rulers images reflecting their own power. The factor Thomas Aldworth reports one such image, a portrait of 'Tamerlane', which was given to the Emperor Jahangir. 'We think [the picture] will content him [Jahangir] above all,' Aldworth stated, given that Jahangir 'derives himselfe' from the Tartar conqueror. ${ }^{57}$

Similarly, the imagery of Timur presented in European texts often showed him in ways that made him appealing to European readers. Joel H. Kaplan has suggested, for example, that the engraving printed in Middleton's The Triumphs of Integrity (1623) portrays him as 'an inspiring example of upward mobility: a

\footnotetext{
54 Barbour, Before Orientalism, 25.

55 Marcus Milwright, "So Despicable a Vessel: Representations of Tamerlane in Printed Books of the Sixteenth and Seventeenth Centuries", Muqarnas, 23 (2006), 317-44 (317). 56 Rick Bowers. "Tamburlaine Engraved, 1622 to 1673", Huntington Library Quarterly 59:4 (1996), 542-549.

57 Thomas Aldworth, Letters, II, p. 138, quoted in Barbour, Before Orientalism, 171.
} 
pagan success story'. 58 Marcus Milwright has pointed out that the plate of 'Tamerlane' in the 1593 printed edition of Marlowe's play is taken from a 1587 pamphlet, in which the image represents an English knight [Fig. 1 and Fig. 2 please see end of article].59 The illustration of Timur in Knolles' Generall Historie is similarly European in appearance. Such visual images not only promote Timur as a potentially heroic and admirable figure, but are also, as Milwright notes, surprisingly Western, and unfixed in religious and ethnic terms. Here as elsewhere, the portrayal of Timur is moulded to meet the needs of the text or the interests of the audience concerned. In his reading of the stage Tamburlaine, Vitkus sees him as 'a hybrid figure - a Scythian played by an English actor'. ${ }^{60}$ In visual representation, Timur/ Tamburlaine remains essentially hybrid: in the engraving from the printed Tamburlaine, his Islamic, Asian identities are superimposed on an image of English chivalry.

Both the dramatic and non-dramatic literature of the Elizabethan period contained numerous references to Tamerlane or Timur. ${ }^{61} \mathrm{He}$ clearly had a presence as a historical figure that was well established prior to Marlowe's popularizing of his story in the Tamburlaine plays. But those plays were highly influential both on the drama of the period and its travel writing, 'legendary' in their contemporary influence and response. ${ }^{62}$ Given the enormously popularity of Marlowe's plays, amongst the first popular successes of London's public theatre, it is unsurprising that the 'Tamburlaine' present in travel writing is often mediated

\footnotetext{
58 Joel H. Kaplan, “Middleton's Tamburlaine”, English Language Notes 13 (1976), 258-60 (260).

${ }^{59}$ Milwright, 321.

60 Vitkus, Turning Turk, 23.

61 See Artemel, 202.

62 Linda McJannet, The Sultan Speaks: Dialogue in English Plays and Histories about the Ottoman Turks (Basingstoke: Palgrave Macmillan, 2006), 81.
} 
by Marlowe. When Coryate speaks to Jahangir of his wish to 'visit the blessed Sepulcher of ... Tamberlaine', he is obviously talking of a historical figure; but in stating that 'perhaps he is not altogether so famous in his own country of Tartaria, as in England', Coryate is surely thinking of the success of Marlowe's plays and their printed editions, which did so much to 'publish' Timur's 'fame'. As Jonathan Gil Harris has argued, Coryate is here 'referring to the historical Tamburlaine', but 'his imagination is clearly inspired by the theatrical one'. Coryate, Harris suggests, identified with this image of Tamburlaine, 'the highly histrionic shape-shifter of humble provincial origins who got to perambulate around Asia delivering mighty lines.' 63 Coryate's 'Tamberlaine' is as much a figure of the stage as of history: Tamburlaine rather than Timur.

References to Timur in a range of contemporary travel writings further suggest the direct influence of the theatrical Tamburlaine. Thomas Roe, as we saw above, thought of the Tamburlaine plays when he was given the gold cloth by Sultan Khurram. ${ }^{64}$ Roe mistrusts the gift from Khurram, perhaps because he dislikes the ostentation; perhaps, as Kate Teltscher suggests, because he suspects the prince's integrity. ${ }^{65}$ As Teltscher and others have noted, Roe fails to appreciate the presentation of the khilat, or robe of honour, reading it as a gawdy costume and thus 'turn[ing] a compliment into an insult'. 66 His understanding that the gift is intended to convey the 'highest favour' is secondary to his association of such

63 Jonathan Gil Harris, The First Firangis: Remarkable Stories of Heroes, Healers, Charlatans, Courtesans \& other Foreigners who Became Indian (New Delhi: Aleph, 2015), 208.

64 Purchas, iv, 381.

65 Kate Teltscher, India Inscribed: European and British Writing on India 1600-1800 (Delhi: Oxford University Press, 1995), 21.

66 Teltscher, 21. See also Bernard S. Cohn, "The Command of Language and the Language of Command", Subaltern Studies IV (1985), 278. 
garments with the theatrical figure, indicating the strength of the impression made by the visual aspects of staging. At the Mogul court, Roe cannot help but notice the similarity between princely clothing and theatrical costume; to put on another man's golden cloak is, to him, an uncomfortable act of theatricality. In the presence of the historical Timur's descendant, it is Marlowe's Tamburlaine whom Roe calls to mind.

There are two further instances of the influence of the visual aspects of staging that merit consideration here. The first of these is the iron cage in which the stage Tamburlaine imprisons Bajazeth, and in which Bajazeth appears in Act Four Scene Two of Part I. In his reading of Robert Vaughan's engraving of 'Tamerlane Emperour of Tartarie', first printed in The Pourtraitures at Large of Nine Moderne Worthies of the World in 1622, and in Thomas Middleton's The Triumphs of Integrity the following year, Rick Bowers draws our attention to the engraving's caption:

TAMERLANE Emperour of Tartarie called the wrath of God and the terrour of the World, He overthrew and tooke prisoner BAZAZET Great Emperour of the Turkes, shutting him up in an Iron Cage: His Army consisting of 100000. men. He also conquered Mesepotamia, Babilon, with the Kingdome of Persia. He died 1402.

[Fig. 3: Vaughan engraving of Tamerlane - please see end of article]

As Bowers notes, this caption echoes Marlowe's play, where Tamburlaine calls himself 'the scourge and wrath of God / The only fear and terror of the world' (Part $I, 3.3 .44-5)$. The fact that the cage in which Bajazeth is imprisoned is iron is most likely also taken from Marlowe's text, rather than the 'passing reference' to the iron nature of the cage made by Whetstone, as Bowers points out, some thirty five 
years before. ${ }^{67}$ When travel writers mention Bajazeth's cage, they frequently note that its bars are made of iron. William Lithgow, for example, in his account of his travels in Asia which was published in 1640, describes Bajazeth's imprisonment as follows:

Bajazet being taken, was carried about in an Iron Cage, on whose necke Tamberlane used to set his foote, when he mounted on horse-backe; and at last beat out his owne braines against the barres of the Iron Cage. ${ }^{68}$ When Tamburlaine's name is mentioned in travel writing of the early to midseventeenth century, his treatment of Bajazeth is often briefly described, and the iron quality of the cage's bars is usually noted. The iron cage became a fact of the story, repeated by Peter Heylyn in Microcosmos (1625), and Alexander Ross in his History of the World (1652). ${ }^{69}$ Such sources often note that Bajazeth committed suicide by beating his head against these iron bars: Heylyn records that Bajazeth 'beat out his braines' against the iron bars, and Ross that he 'dasheth out his brains against the iron grates of his Cage'. The powerful dramatization of this event in Act Five Scene Two of Part I echoes in the travel writings and histories that tell the story of the historical Tamerlane.

The second visual element to be considered is the map with which Tamburlaine measures his empire in Act Five Scene Four of Part II. Like Bajazeth's iron cage, Tamburlaine's map is an example of a prop used in the staging of the

\footnotetext{
67 Rick Bowers, "Tamburlaine Engraved, 1622 to 1673", Huntington Library Quarterly 59:4 (1996), 542-549 (546).

68 William Lithgow, The totall discourse, of the rare adventures, and painefull peregrinations of long nineteene yeares travailes from Scotland, to the most famous kingdomes in Europe, Asia, and Affrica Perfited by three deare bought voyages, in surveying of forty eight kingdomes ancient and modern; twenty one rei-publicks, ten absolute principalities, with two hundred islands (1640), 172.

${ }^{69}$ Microcosmos (1625), 545; Alexander Ross, History of the World (1652), 49-50.
} 
plays which finds its way into the travel narratives and histories of the period. The Tamburlaine plays have long been understood as having been 'directly inspired by a "real" map', Ortelius's 1570 Theatrum Orbis Terrarum. ${ }^{70}$ In the final scene of the play, Tamburlaine calls for a map to be brought to him:

Give me a map, then let me see how much Is left for me to conquer all the world, That these boys may finish all my wants. ${ }^{71}$

Tamburlaine traces the trajectory of his conquests across the physical map: 'Here I began to march towards Persia, [...] Then marched I [...] I conquered all as far as Zanzibar [...] I came at last to Grecia, and from thence / To Asia' (5.4.126, 130, 139, 141-2). The map allows him to chart his successes, but its record of the land he has not yet brought under his power is a testimony to the limitations of that power:

Look here, my boys. See what a world of ground Lies westward from the midst of Cancer's line [...] And shall I die, and this unconquerèd? [...] And shall I die, and this unconquerèd? (Part II, 5.4.145-6, 150, 158)

The theatrical Tamburlaine is surely in Edward Terry's mind when he describes Emperor Jahangir's similar encounter with a map in A voyage to East-India (1655). Terry explains that the Mogul is descended from Tamerlane, and that his status as 'conqueror of the world' comes directly from 'his great Ancestor'. Terry likens Jahangir to Tamburlaine in both lineage and grandiosity, with their numerous

\footnotetext{
${ }^{70}$ John Gillies, Shakespeare and the Geography of Difference (Cambridge: Cambridge University Press, 1994), 59; Ethel Seaton, "Marlowe's Map", Essays and Studies by Members of the English Association 10 (1924), 13-35, repr. In Marlowe: A Collection of Critical Essays, ed. by Clifford Leech (Englewood Cliffs, NJ: Prentice-Hall, 1964).

${ }^{71}$ Christopher Marlowe, The Second Part of the Bloody Conquests of Mighty

Tamburlaine, ed. by Mathew R. Martin (London: Broadview, 2014), 5.4.123-5.
} 
shared titles. ${ }^{72}$ In his account of Jahangir, this status is challenged by the English ambassador, who presents Jahangir with a map that shows his empire to be rather more limited than his status as world-conqueror would suggest:

my Lord-Ambassador, haveing businesse with him, and upon those terms; there is no coming unto that King empty handed without some present, or other (of which more afterward) and having at that time nothing left, which he thought fit to give him, presented him with Mercators great book of Cosmography (which the Ambassador had brought thither for his own use) telling the Mogol that that book described the four parts of the world, and all several Countreys in them contained, the Mogol at the first seem'd to be much taken with it, desiring presently to see his own Territories, which were immediately shewen unto him, he asked where were those Countreys about them, he was told Tartaria, and Persia, as the names of the rest which confine with him, and then causing the book to be turn'd all over, and finding no more to fall to his share, but what he first saw, and he calling himself the Conqueror of the world, and having no greater share in it, seemed to be a little troubled, yet civily told the Ambassadour that neither himself, nor any of his people did understand the language in which that book was written, and because so, he further told him that he would not rob him of such a Jewel, and therefore returned it unto him again. ${ }^{73}$

Both Jahangir in Terry's account and Tamburlaine in Marlowe's play refuse to accept the constraints of a map on their own desires or perception of their powers; the physical map serves as evidence of the ruler's limitations of power and lack of control over geography, in contrast to their self-perception.

Richard Levin has argued that the theatrical Tamburlaine was intended to 'evoke the audience's wonder or admiration', much as the literature of travel sought to evoke these responses in its readers by describing encounters with rich and unfamiliar foreign rulers. ${ }^{74}$ In describing their experiences in foreign lands, English travellers often used theatrical metaphor in order to explain or excuse

\footnotetext{
72 On Jahangir's name and heritage see Sanjay Subrahmanyam, "On World Historians in the Sixteenth Century", Representations 91: 1 (2005), 26-57.

73 Terry, $x$.

74 Richard Levin, "The Contemporary Perception of Marlowe's Tamburlaine", Medieval \& Renaissance Drama in England 1 (1984), 51-70 (55).
} 
both other people's behaviour and their own. The figure of Tamerlane, whether in history, travel narrative or play, could be re-fashioned to meet the particular needs of the source in question. The unfixed nature of his identity, simultaneously Scythian, Persian, Muslim, and anti-Turk, meant he was adaptable to a number of different requirements. In evoking the reader's wonder, early modern travellers naturally turned to the stage figure of Tamburlaine, who inspired a host of imitators and made the name of the player who portrayed him, Edward Alleyn. ${ }^{75}$ Thomas Coryate, of course, never made it to Tamburlaine's 'blessed Sepulcher'; for him, as for other travellers in the early seventeenth century, the Tamburlaine that he knew best was not the historical figure, but the tyrant of Marlowe's plays.

75 On Alleyn's performance as Tamburlaine, see for example Jonathan Gil Harris, Untimely Matter in the Time of Shakespeare (Philadelphia: University of Pennsylvania Press, 2009), 78. 


\section{Tambirlaine, the great.}

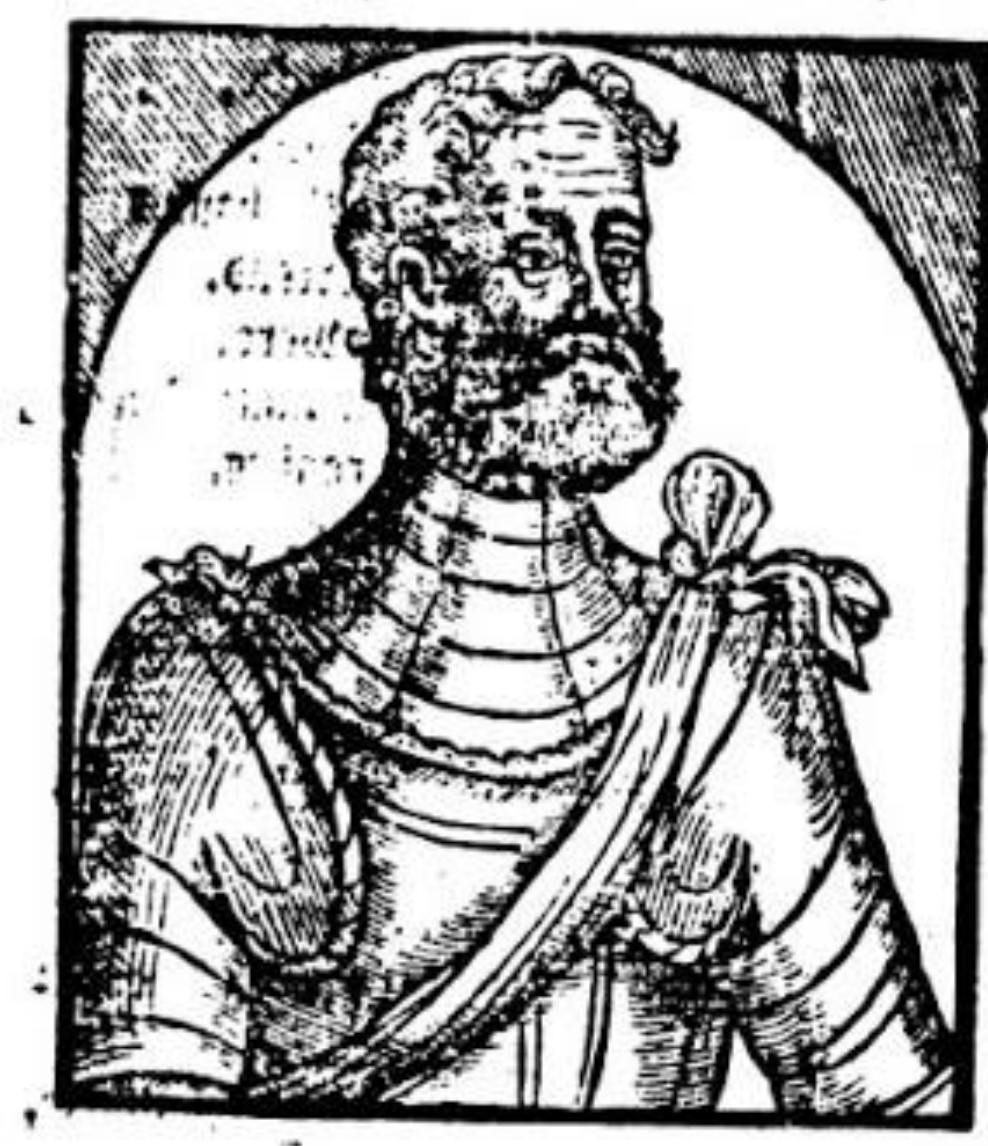

Fig. 1: engraving of Tamburlaine from 1593 edition of the Tamburlaine plays 


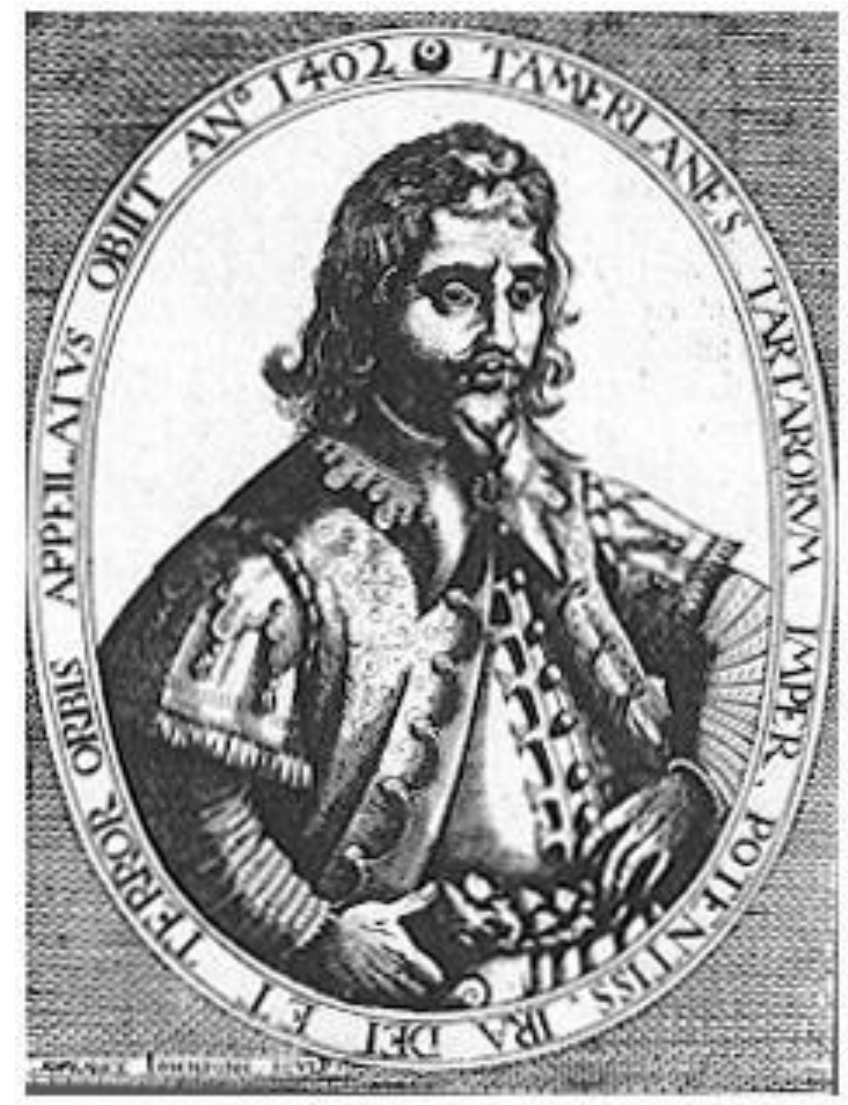

Fig. 2: Illustration of the historical "Tamerlane” from Richard Knolles' Generall Historie of the Turkes (1603) 


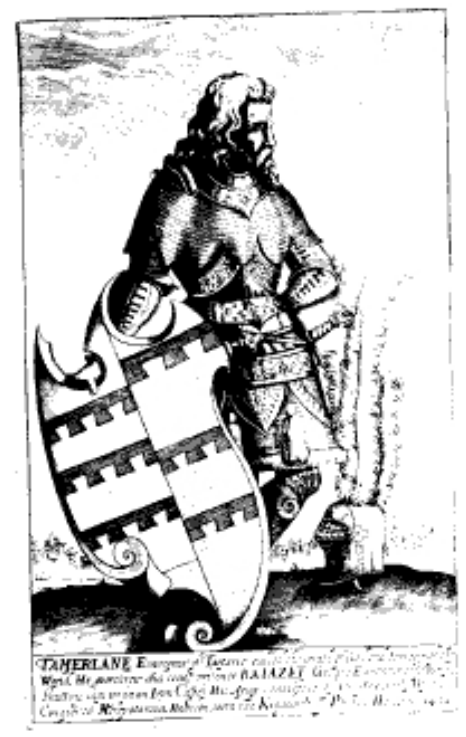

Fig. 3: Vaughan engraving of Tamerlane (1622) 